\title{
Investigation of the Erosive Wear Resistance of Boronized Ash-Blowing Nozzles
}

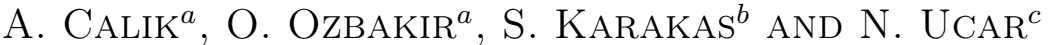 \\ ${ }^{a}$ Manufacturing Engineering Department, Faculty of Technology, Suleyman Demirel University, Isparta, Turkey \\ ${ }^{b}$ Materials Science and Engineering Department, Faculty of Engineering, Cankaya University, Ankara, Turkey \\ ${ }^{c}$ Physics Department, Faculty of Arts and Sciences, Suleyman Demirel University, Isparta, Turkey
}

(Received August 4, 2016)

In this study, pack boronizing was applied to ash-blowing nozzles manufactured from AISI 1040 steels using Ekabor II powders as the boronizing source at a temperature of $1273 \mathrm{~K}$ for a duration of $8 \mathrm{~h}$. Erosive wear tests of boride ash-blowing nozzles were carried out in ash delivery line of thermal reactor under actual working conditions. It was observed that erosive wear resistance of borided ash-blowing nozzles were increased 3 times as a result of the boronizing process. The improved wear resistance of the borided samples can be explained by increased surface hardness and higher work hardening.

DOI: 10.12693/APhysPolA.131.252

PACS/topics: boriding; wear resistance; boride layer; hardness

\section{Introduction}

Ash-blowing nozzles are used in the ash transfer systems of thermal power plants. These nozzles are exposed to erosive wear due to the impact of abrasive ash particles $[1,2]$. To improve these properties, surfacehardening process must be applied to it. Surface hardening processes can impart many advantages such as high service life, high wear resistance at low cost $[3,4]$. One such surface hardening process is boronizing, a thermochemical surface treatment in which boron atoms diffuse into the surface of the work piece to form hard borides with the base material [5-7]. Corresponding to this, it has been shown that the borided steels exhibit high hardness (about $2000 \mathrm{HV}$ ), high wear resistance and improved corrosion resistance [8-10]. In addition to this, it has been pointed out that the wear resistance of boronized steels is higher against alumina abrasives than against silicon carbide abrasives due to relative hardness of these materials [11]. This result shows that there is usually a proportional relationship between the hardness of the sample and the wear resistance.

Much work has been carried out on the wear resistance of borided steels of various composition, investigated under many different testing conditions [12-15]. Green et al. [14] investigated the erosion mechanisms of low carbon AISI 1050 steel in relation to the carbon content and microstructure. In addition, the high wear resistance of carbide free bainite steels is attributed to their fine ferritic laths surrounded by austenitic films. On the other hand, Er and Par [15] showed that surface hardness and abrasive wear resistance of boronized AISI 1008 and AISI 1045 steels are much better than the untreated ones. They obtained that the wear rates of untreated AISI 1008 steel specimens is 10.7 to 12.6 times higher than the boronized specimens. The aim of the present research was to investigate the erosive wear performance of borided ash-blowing nozzle manufactured from AISI 1040 steels in ash delivery line of thermal reactor under actual working conditions.

\section{Experimental details}

The ash-blowing nozzle manufactured from AISI 1040 steels was cylindrical in shape of $45 \mathrm{~mm}$ in diameter and $38 \mathrm{~mm}$ in length. Chemical composition of the steels were shown in Table I.

TABLE I

Chemical compositions of the AISI 1040 steel used in this study.

\begin{tabular}{c|c|c|c|c|c|c|c}
\hline \hline $\mathrm{C}$ & $\mathrm{Si}$ & $\mathrm{Mo}$ & $\mathrm{Mn}$ & $\mathrm{Cr}$ & $\mathrm{S}$ & $\mathrm{P}$ & $\mathrm{Fe}$ \\
\hline 0.42 & 1.10 & 0.50 & 1.52 & 1.44 & 0.024 & 0.026 & bal.
\end{tabular}

Boronizing was carried out at $1273 \mathrm{~K}$ for $8 \mathrm{~h}$ with a commercial boronizing agent Ekabor II powders. Microstructural analysis of borides formed on cross-sections of the ash-blowing nozzle that manufactured from AISI 1040 steels samples was performed with optical and scanning electron microscopy (SEM). The presence of borides on the surface of the borided ash-blowing nozzle was determined by using the X-ray diffractometer. To determine the hardness of the borided specimens a Vickers microhardness tester was utilized with an applied load of $50 \mathrm{~g}$ and dwell time of $5 \mathrm{~s}$. Many indentations were made on each coating film under each experimental condition to check the reproducibility of hardness data.

Erosive wear tests of the untreated and borided ashblowing nozzles manufactured from AISI 1040 steels were carried out in ash delivery line of the thermal reactor under with actual working conditions. The wear losses were determined from mass losses measured from the nozzles.

\section{Results and discussion}

Optical microscope and scanning electron microscopy cross-sectional examinations of boronized ash-blowing nozzle that manufactured from AISI 1040 steels are presented in Fig. 1.

As seen from these figures, the boride layer has a sawtooth morphology; this structure was evenly distributed over the surface. On the other hand, the XRD analysis 


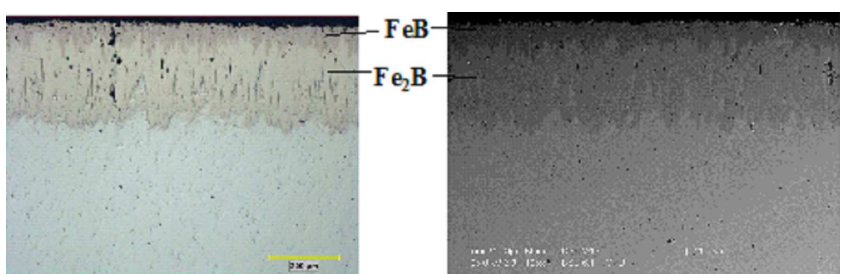

Fig. 1. Optical (left) and SEM (right) micrograph of cross-section of borided ash-blowing nozzle manufactured from AISI 1040 steels. Boriding was carried out at $1273 \mathrm{~K}$ for $8 \mathrm{~h}$ using Ekabor II powders.

confirmed that the boride layer layer consists of $\mathrm{FeB}$ and $\mathrm{Fe}_{2} \mathrm{~B}$ phases (Fig. 1 and Fig. 2). In general, boriding of carbon steels usually leads to formation of two borides, $\mathrm{FeB}$ and $\mathrm{Fe}_{2} \mathrm{~B}$, FeB near the surface and $\mathrm{Fe}_{2} \mathrm{~B}$ in the vicinity of the steel matrix. In this study, the total boride layer thickness (including $\mathrm{FeB}$ and $\mathrm{Fe}_{2} \mathrm{~B}$ layers) was measured at approximately $220 \mu \mathrm{m}$ as shown in Fig. 1.

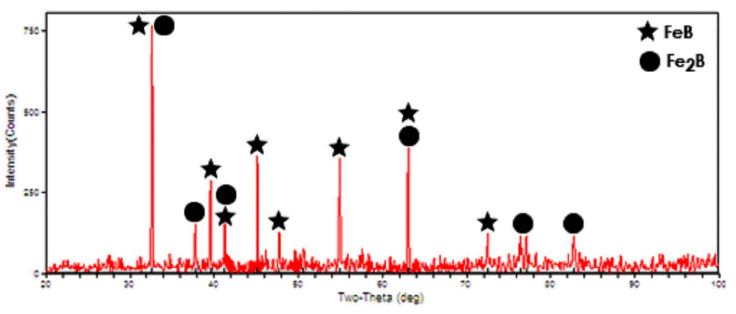

Fig. 2. X-ray diffraction pattern of borided ashblowing nozzle that was manufactured from AISI 1040 steels at $1273 \mathrm{~K}$ for $8 \mathrm{~h}$.
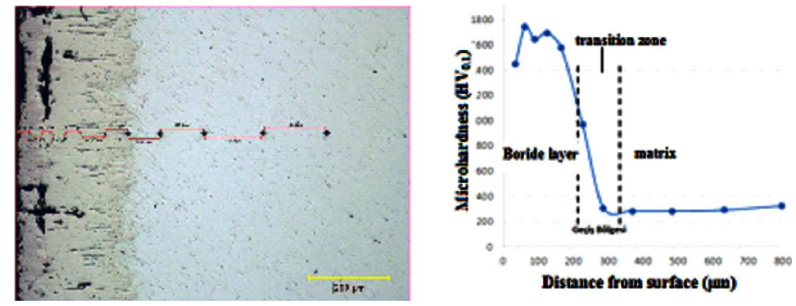

Fig. 3. View of Vickers indentations (left) and microhardness (right) from the outer layer to the interior of the base material in borided ash-blowing nozzle that was manufactured from AISI 1040 steels at $1273 \mathrm{~K}$ for $8 \mathrm{~h}$.

Hardness measurements showed that the hardness of the borides were much higher than that of the base steels (Fig. 3). In the boride layers, average value of micro-hardness about $1740 \mathrm{HV}_{0.1}$ was obtained, whereas the hardness of substrate was $283 \mathrm{HV}_{0.1}$. It can be understood that the hardness of the boride layer is much higher than the substrate. This is a consequence of the presence of hard $\mathrm{FeB}$ and $\mathrm{Fe}_{2} \mathrm{~B}$ phases.

The life of ash-blowing nozzles exposed to erosive wear due to abrasive ash in the ash delivery line was determined in real working conditions as shown in Fig. 4.

Weight loss measurements of the ash-blowing nozzle was made with 10 day $(240 \mathrm{~h})$ intervals. At the end
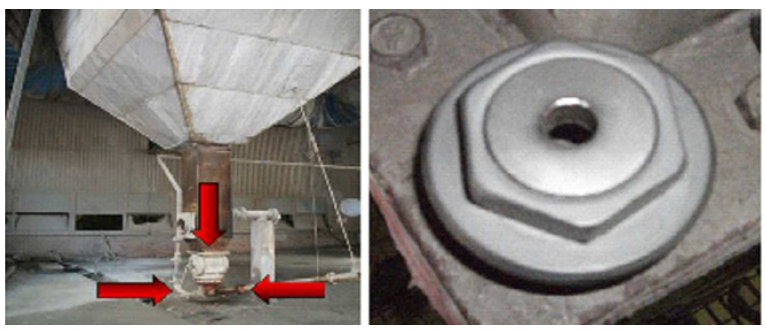

Fig. 4. The location of ash-blowing nozzles in ash delivery system (left) and view of ash-blowing nozzle (right).

of 60 days $(1440 \mathrm{~h})$ of operation, the untreated nozzles became inoperable due to erosion by the abrasive ash (Fig. 5).

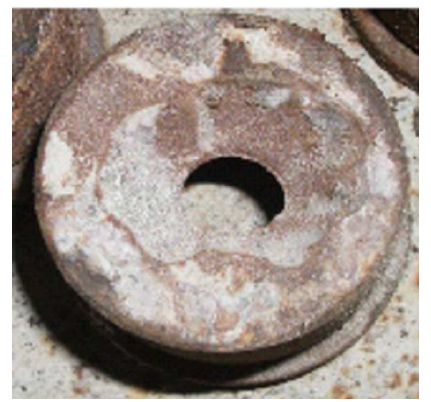

Fig. 5. Erosion failure of ash-blowing nozzle.

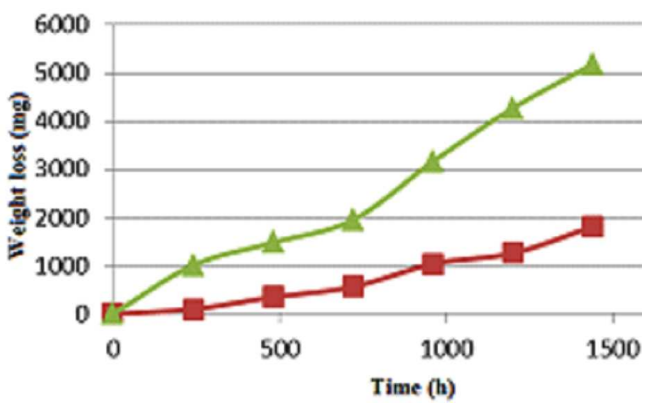

Fig. 6. Mass loss versus time curves for the untreated $(\boldsymbol{\Delta})$ and borided $(\boldsymbol{\square})$ nozzle.

After the entire operation period, the total weight loss values were 5.18 and $1.81 \mathrm{~g}$ for unborided and borided ash-blowing nozzle, respectively. The total weight loss of boronized ash-blowing nozzles decreased by a factor of 3 times (Fig. 6) as a result of the boronizing treatment. To sum up, the borided ash-blowing nozzle that manufactured from AISI 1040 steels exhibited high wear resistance in comparison with the unborided ones. The improved wear resistance of the borided ash-blowing nozzles can be explained by its higher hardness. In the literature $[15,16]$, surface hardness and abrasive wear resistance of boronized steels are much better than the untreated ones. Conversely, Atik et al. [17] showed that wear strengths is not directly related to boride layer thickness and hardness. In conclusion, the wear resistance de- 
pends on the factors like matrix materials, matrix hardening agents, temperature, erodent and abrasion particles. This confirms that wear strength is not a material-specific property but a system property.

\section{Conclusions}

In this study, the wear resistance of ash-blowing nozzles manufactured from AISI 1040 steel were evaluated by and compared in a true work environment of a thermal power plant. The results showed high wear resistance in the borided ash-blowing nozzles in comparison with the untreated ones due to high hardness in the borided ash-blowing nozzles.

\section{Acknowledgments}

This work was supported by the scientific research grant of the Suleyman Demirel University (No. SDU.BAP.4005-YL1-14).

\section{References}

[1] E. Yuruker, The Effect of Erodent Particle Size Distribution on Erosive Wear, Kocaeli University, Thesis, İzmit 2010, (in Turkish).

[2] M. Bagci, H. Imrek, in: 5th International Advanced Technologies Symposium (IATS 2009), Karabük (Turkey), Eds. M. Acarer, H.I. Demirci, C. Gologlu, Karabük University Press, Karabük (Turkey) 2009, p. 765

[3] E. Atik, Mater. Struct. 31, 418 (1998).

[4] C.H. Xu, J.K. Xi, W. Gao, J. Mater. Process. Technol. 65, 1 (1997).
[5] A.G. Matuschka, Boronising, Carl Hanser Verlag, München 1980.

[6] B. Selcuk, R. Ipek, M.B. Karamis, V. Kuzucu, J. Mater. Process. Technol. 103, 310 (2000).

[7] S. Sahin, C. Meric, Mater. Res. Bull. 37, 971 (2002).

[8] A.K. Sinha, in: ASM International Handbook, Vol. 4, The Materials International Society, Materials Park (OH) 1991, p. 437.

[9] B.S. Mann, Wear 208, 125 (1997).

[10] R. Hu, G.R. Fenske, L.E. Rehn, P.M. Baldo, A. Erdemir, R.H. Lee, R.A. Erck, Surf. Coat. Technol. 42 , 3 (1990).

[11] A.G. Wang, I.M. Hutchings, Wear 124, 2 (1988).

[12] U. Sen, Thin Solid Films 483, 152 (2005).

[13] E. Garcia-Bustos, M.A. Figueroa-Guadarrama, G.A. Rodríguez-Castro, O.A. Gómez-Vargas, E.A. Gallardo-Hernández, I. Campos-Silva, Surf. Coat. Technol. 215, 241 (2013).

[14] G.M. Green, R. Taggart, D.H. Polonis, Metallography 14, 3 (1981).

[15] U. Er, B. Par, in: in: 2nd International Boron Symposium, Eds. H. Ozdag, H. Akdas, V. Bozkurt, M. Iphar, Osmangazi University Press, Eskisehir (Turkey) 2004, p. 207.

[16] E. Yilmaz, N. Ucar, A. Calik, S. Karakas, R. Selbas, J. Balkan Tribol. Assoc. 17, 4 (2011).

[17] E. Atık, U. Yunker, C. Merıc, Tribol. Int. 36, 155 (2003). 